\title{
VERNALIZING PRE-TRANSPLANTS IMPROVED THE AGRONOMIC CHARACTERISTICS OF STRAWBERRY GENOTYPES UNDER TROPICAL CONDITIONS ${ }^{1}$
}

\author{
VICTORIA ROSSMARY SANTACRUZ OVIEDO ${ }^{2 *}$, CIPRIANO RAMON ENCISO-GARAY ${ }^{3}$, ERNESTO ISAAC \\ GARCIA FIGUEREDO ${ }^{3}$
}

\begin{abstract}
Strawberry plant yields improve if they accumulate a certain number of cold hours, which does not occur naturally under tropical and subtropical climatic conditions. This study evaluated the agronomic characteristics of potted transplants from 14 strawberry genotypes that had been subjected to vernalization treatment prior to planting in the field. The transplants were stored in a cold chamber at $5^{\circ} \mathrm{C}$ for $576 \mathrm{~h}$. The genotypes used in the experiment were Camino Real, Festival, Florida Eliane, Sweet Charlie ${ }_{\mathrm{fp}}$, Sweet Charlie, Dover, IAC Guaraní, Corea, Early Bright, and hybrid clones Dover $\times$ Rosalinda $_{1}$, Dover $\times$ Rosalinda $_{4}$, Dover $\times$ Oso Grande, Dover $\times$ Esplendida, and Dover $\times$ Aichi. The 14 genotypes in the control group received no vernalization treatment. Each experimental unit consisted of 15 plants. A randomized complete blocks experimental design was used with a $14 \times 2$ factorial arrangement and three repetitions. Subjecting the strawberry transplants to the vernalization treatment had a significant effect on the total number of fruits per plant and total and commercial yield of fruits per plant, but there was no significant interaction between the factors and the evaluated yield and growth characteristics. Dover $\times$ Oso Grande, Florida Eliane, Camino Real, and Festival produced the greatest numbers of large fruits per plant. Vernalizing strawberry transplants increased the yield and the number of medium and small sized fruits per plant. The results showed that vernalization is a technique that could be used in tropical climate conditions to improve strawberry cultivation productivity.
\end{abstract}

Keywords: Fragaria $\times$ ananassa Duch. Genotypes. Vernalization. Yield.

\section{VERNALIZANDO PRÉ-TRANSPLANTES MELHORAM AS CARACTERÍSTICAS AGRONÔMICAS DE GENÓTIPOS DE MORANGO EM CONDIÇÃO TROPICAL}

RESUMO - O rendimento da planta de morango melhora si acumularem uma certa quantidade de horas frias, o que não ocorre naturalmente em condições de clima tropical e subtropical. Este estudo avaliou características agronómicas de 14 genótipos de morango sometidos a vernalização das mudas, produzidas em vasos, antes do transplante a campo. As mudas foram armazenadas em câmara fria a $5{ }^{\circ} \mathrm{C}$ por um período de 576 horas. Os genótipos avaliados foram Camino Real, Festival, Florida Eliane, Sweet Charlie ${ }_{\mathrm{fp}}$, Sweet Charlie, Dover, IAC Guaraní, Corea, Early Bright, e clones híbridos Dover $\times$ Rosalinda $_{1}$, Dover $\times$ Rosalinda $_{4}$, Dover $\times$ Oso Grande, Dover $\times$ Esplendida e Dover $\times$ Aichi. Os 14 genótipos do grupo controle não receberam tratamento de frio. Cada unidade experimental foi composta por 15 plantas. O delineamento utilizado foi o de blocos casualizados, em esquema fatorial $14 \times 2$, com três repetições. Não houve interação significativa entre os fatores para as características avaliadas, mas houve efeito significativo da vernalização das mudas sobre número total de frutos por planta, produção total e comercial de frutos por planta. 'Dover x Oso Grande', 'Florida Eliane', 'Camino Real' e 'Festival' produziram a maior quantidade de frutos grandes por planta. Vernalizando as mudas de morango aumentaram o número de frutos médios e pequenos por planta. Pelos resultados obtidos pode se concluir que a vernalização é uma técnica que poderia ser utilizada em condições de clima tropical para melhorar o cultivo e aumentar a produtividade do cultivo de morango.

Palavras - chave: Fragaria × ananassa Duch. Genótipos. Vernalização. Produção.

\footnotetext{
${ }^{*}$ Corresponding author

${ }^{1}$ Received for publication in 02/20/2020; accepted in 04/07/2020.

Paper extracted from project research from authors.

${ }^{2}$ Research Department, Universidad Nacional de Asunción, San Lorenzo, Central, Paraguay, vrossmary@hotmail.com - ORCID: 00000001-5131-9415.

${ }^{3}$ Plant Production Area, Universidad Nacional de Asunción, San Lorenzo, Central, Paraguay, crenciso@hotmail.com - ORCID: 0000-00028691-2689, garciaernesto1092@hotmail.com - ORCID: 0000-0003-0837-9177.
} 


\section{INTRODUCTION}

Strawberry (Fragaria $\times$ ananassa (Duchesne ex Weston) Duchesne ex Rozier) is a crop that is highly suited to family farming because requires large amounts of labor to cultivated it and produce fruit. The high perishability of its fruits and their growth for direct consumption, mainly in natura, juices, and jams mean that its cultivation in Paraguay is concentrated around urban centers (GUILLEN; ZARZA; DELGADO, 2019; OVIEDO et al. 2018).

Strawberry flowering is dependent on a set of environmental factors, such as temperature, photoperiod, and the interaction between them (HEIDE; STAVANG; SØNSTEBY, 2013). Diel et al. (2017) suggested that the interaction between temperature and photoperiod determined the ability of a variety to adapt to an area, whereas the photoperiod controlled the vegetative and reproductive cycle.

Paraguay has a subtropical climate due to its geographical location, which means that there is little variation in temperature (average $22^{\circ} \mathrm{C}$ ) and monthly photoperiod (10.5 to $13.5 \mathrm{~h}$ ) during the year. The most popular strawberry varieties in Paraguay are Dover and Sweet Charlie, which come from the United States and are classified as short day varieties (GUILLEN; ZARZA; DELGADO, 2019; ISATOMI; RAIDAN, 2002). The transplants used to initiate the crops are mostly produced in Paraguay, but small amounts are imported from nurseries in Argentina produced in places with high altitudes, which means that they are naturally vernalized. However, because the average annual temperature is $22^{\circ} \mathrm{C}$ in Paraguay, the transplants produced there do not undergo natural vernalization. Antunes and Peres (2013) remarked that specialized nurseries in Argentina and Chile supply plants to nearly all the countries in South America. Most of these nurseries produce North American cultivars under intellectual property right agreements.

Strawberry cultivation requires between 100 and 400 cold hours below $10^{\circ} \mathrm{C}$ (LAVÍN; MAUREIRA, 2019). Vernalization is the process by which flowering is promoted through prolonged exposure to cold or winter (TAIZ et al. 2017). Artificial vernalization is a low-temperature treatment that provides the required number of cold hours to break dormancy and induce flowering (flower bud differentiation) when this does not occur naturally (COSTA et al., 2014).

In Paraguay, strawberry genetic material from abroad has been introduced and crossings have been made to obtain hybrid clones, which then need to be evaluated in order to diversify the supply of genetic material. Technologies that could increase crop yields, such as vernalizing transplants, also need to be investigated. Ruan et al. (2013) suggested that the adoption of a suitable variety is the key to success when cultivating strawberries in different production systems and environments.

This study aimed to evaluate the agronomic characteristics of strawberry pre-transplants genotypes with and without artificial vernalization under tropical climatic conditions.

\section{MATERIAL AND METHODS}

The field experiment was conducted between April and October, 2015 at the Centro de Investigación Hernando Bertoni (CIHB), which belongs to the Instituto Paraguayo de Tecnologia Agraria (IPTA) Caacupé, Cordillera, Paraguay $\left(25^{\circ}\right.$ $23^{\prime} 16.38^{\prime \prime} \mathrm{S}, 57^{\circ} 11^{\prime} 22.24^{\prime \prime} \mathrm{W}$ and 228 m.a.s.l).

The soil in the experimental area is an Ultisol and has a sandy loam texture (LOPEZ, 1995). The extracted soil sample had the following attributes: $\mathrm{pH}=6.6$, organic matter $=1.20 \%, \mathrm{P}=141.59$ $\mathrm{mg} \mathrm{dm}{ }^{-3}, \mathrm{Ca}^{2+}=1.20 \mathrm{cmol}_{\mathrm{c}} \mathrm{dm}^{-3}, \mathrm{Mg}^{2+}=0.63 \mathrm{cmol}_{\mathrm{c}}$ $\mathrm{dm}^{-3}, \mathrm{~K}^{+}=0.07 \mathrm{cmol}_{\mathrm{c}} \mathrm{dm}^{-3}$, and $\mathrm{Al}^{3+}+\mathrm{H}^{+}=0$.

The local climate is subtropical and the average minimum and maximum temperatures are $19^{\circ} \mathrm{C}$ and $29^{\circ} \mathrm{C}$, respectively. The average annual temperature is $24^{\circ} \mathrm{C}$ and the average annual rainfall is $1536 \mathrm{~mm}$. The temperature and precipitation data for the experimental period (Figure 1) were provided by the CIHB agrometeorology station.

Figure 1. Temperature and precipitation averages during the experimental period.

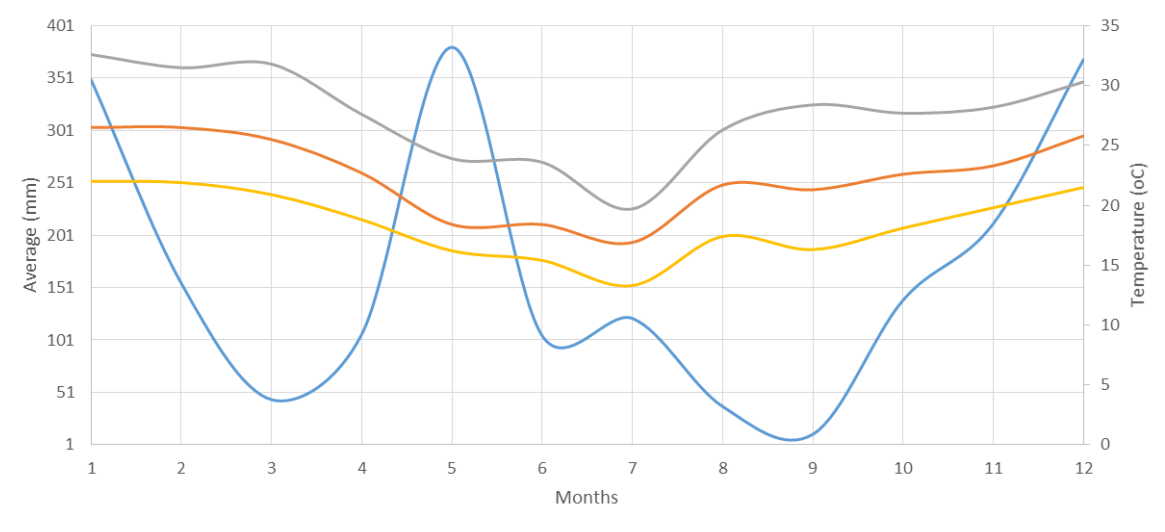


The genotypes used were provided by the Hernando Bertoni Research Center (CIHB). These were Camino Real, Festival, Florida Eliane, Sweet Charlie $_{\text {fp }}$ (from a farm owned by the producer), Sweet Charlie, Dover, IAC Guaraní, Corea, Early Bright, and hybrid clones Dover $\times$ Rosalinda $_{1}$, Dover $\times$ Rosalinda $_{4}$, Dover $\times$ Oso Grande, Dover $\times$ Esplendida, and Dover $\times$ Aichi. All these materials belong to the CIHB strawberry collection.

The 28 treatments consisted of the 14 genotypes (nine varieties and five hybrid clones) with and without vernalization. The transplants were raised in plant pots that were $12 \mathrm{~cm}$ high and $10 \mathrm{~cm}$ in diameter. A randomized complete block experimental design was used with a $14 \times 2$ factorial scheme and three replications. Each treatment covered an area of $2.25 \mathrm{~m}^{2}$ and contained 15 plants. The plots were spaced $0.6 \mathrm{~m}$ apart. The vernalization treatments took place in a cold chamber at a constant temperature of $5( \pm 2)^{\circ} \mathrm{C}$ with a photoperiod of $8 \mathrm{~h}$ light and $16 \mathrm{~h}$ darkness. They received the vernalization treatment between March 31 and April 24,2015 , which was $24 \mathrm{~d}$ or $576 \mathrm{~h}$ exposure to cold temperatures. The treatments were carried according to Oliveira and Scivittaro (2009).

In the field, the preparation of the parcel consisted of soil removal with a hand tractor at 15 days and at one day before transplantation. Organic amendments ( $5 \mathrm{~kg} \mathrm{~m}^{-2}$ organic manure) and chemical fertilizers $\left(20 \mathrm{~kg} \mathrm{ha}^{-1} \mathrm{~N} ; 150 \mathrm{~kg} \mathrm{ha}^{-1} \mathrm{P}_{2} \mathrm{O}_{5}\right.$, and 120 $\mathrm{kg} \mathrm{ha}^{-1} \mathrm{~K}_{2} \mathrm{O}$ ) were incorporated as base fertilizers at 15 days before transplantation. The plastic mulching installed had a $30 \mu \mathrm{m}$ gray/white color. The spacing was $40 \mathrm{~cm}$ between rows and $30 \mathrm{~cm}$ between plants. A top dressing fertilization of $40 \mathrm{~kg} \mathrm{ha}^{-1} \mathrm{~N}$ and $60 \mathrm{~kg}$ $\mathrm{ha}^{-1} \mathrm{~K}_{2} \mathrm{O}$ was applied three times during the crop cycle at 30, 60, and 90 days after transplanting (DAT). Harvesting began when the red color had reached $75 \%$ on the fruits and nine central plants from each plot were evaluated.

The characteristics evaluated were total number of fruits per plant (all fruits produced per plant were recorded), total yield per plant $\left(\mathrm{g} \mathrm{plant}^{-1}\right)$, commercial yield per plant $\left(\mathrm{g}\right.$ plant $\left.{ }^{-1}\right)$, commercial and non-commercial number of fruits per plant (fruits $\geq 3 \mathrm{~g}$ and without physical or mechanical damage were considered to be commercial fruits, whereas non-commercial fruits were fruits that were smaller than $3 \mathrm{~g}$, showed signs of disease, and/or had been damaged by insects or other animals), and the numbers of small, medium, large, and noncommercial fruits per plant $\left(\mathrm{g} \mathrm{plant}^{-1}\right)$. The fruits were counted and classified into their respective categories (large $>12 \mathrm{~g}$ ), medium $(6-12 \mathrm{~g}$ ), and small $(3-5 \mathrm{~g})$ fruits. Non-commercial fruits were also included.

The data were subjected to analysis of variance (ANOVA) and significant statistical differences were compared using the Scott-Knott Test at the $5 \%$ probability level by the Infostat ${ }^{\circledR}$ Software program (DI RIENZO, et. al. 2015).

\section{RESULTS AND DISCUSSION}

\section{Total number of fruits per plant and total and commercial fruit yields per plant}

The statistical analyses indicated that there were statistically significant differences among the genotypes and among the vernalization factors (Table 1). The Dover $\times$ Oso Grande, Festival, Dover $\times$ Rosalinda $_{1}$, Dover, Sweet Charlie $\mathrm{f}_{\mathrm{fp}}$, IAC Guarani, and Dover $\times$ Aichi genotypes produced the largest number of fruits per plant, and they were significantly different from the Florida Eliane, Camino Real, Dover $\times$ Rosalinda $_{4}$, Dover $\times$ Esplendida, Early Bright, Sweet Charlie, and Corea genotypes (Table 1). Silva, Dias and Pacheco (2015) reported that Dover produced 94.01 fruits plant $^{-1}$ on average and Sweet Charlie produced 83.86 fruits per plant $^{-1}$

All these values were greater than the values recorded in this study (Sweet Charlie, 17.31 fruits plant $^{-1}$ and Dover, 29.26 fruits plant $^{-1}$ ). The lower number of fruits can be attributed to the late transplanting date (May 8) in this study. This delayed the vegetative development of the plants in the field, which may have restricted fruit development. In addition, rainfall was high and there were more cloudy days in April and May (Figure 1), which led to poor photosynthetic production.

According to Isatomi and Raidan (2002), floral bud differentiation in early varieties begins during the first half of March in Paraguay, and early and mid-April in the intermediate and late cycle varieties, respectively. The high rainfall and large number of cloudy days at the beginning of the season explains why the strawberry plants only developed a small number of leaves before flower bud differentiation began. It is possible that the poor vegetative development led to a reduction in bud differentiation and thus fruit number. Lieten, Kinet and Bernier (1995) suggested that long periods of vernalization can delay fruit production and decrease yields due to the short flower bud differentiation period.

The Dover $\times$ Oso Grande genotype only began producing fruits in the first half of July, which could have favored vegetative development and led to the larger number of fruits produced per plant (32.83 fruits per plant ${ }^{-1}$ ) compared to some of the other varieties. 'Festival' and 'Camino Real' also showed late development behavioral characteristics. 
Furthermore, harvesting occurred on the same date for all genotypes and this meant that there were still immature flowers and fruits on Festival and Camino Real. This may have affected yield and could explain why Fontana et al. (2016) in Rio Grande do Sul,
Brazil, obtained 20.57 fruits plant ${ }^{-1}$ and a 395.35 $\mathrm{g}$ plant $^{-1}$ average yield from the Camino Real genotype, which were higher values than those obtained in this study.

Table 1. Variance analysis results for the total number of fruits, and total and commercial yields per plant for each strawberry genotype.

\begin{tabular}{cccc}
\hline Genotypes & $\begin{array}{c}\text { Total number of } \\
\text { fruits plant }^{-1}\end{array}$ & $\begin{array}{c}\text { Total yield } \\
\left(\mathrm{g} \mathrm{plant}^{-1}\right)\end{array}$ & $\begin{array}{c}\text { Commercial yield } \\
\left(\mathrm{g} \mathrm{plant}^{-1}\right)\end{array}$ \\
\hline Dover $\times$ Oso Grande & $32.83 \mathrm{~A}$ & $391.11 \mathrm{~A}$ & $374.10 \mathrm{~A}$ \\
Festival & $24.81 \mathrm{~A}$ & $292.28 \mathrm{~B}$ & $284.22 \mathrm{~B}$ \\
Dover $\times$ Rosalinda & $29.09 \mathrm{~A}$ & $278.70 \mathrm{~B}$ & $263.48 \mathrm{~B}$ \\
Florida Eliane & $19.63 \mathrm{~B}$ & $274.37 \mathrm{~B}$ & $266.43 \mathrm{~B}$ \\
Camino Real & $18.28 \mathrm{~B}$ & $271.94 \mathrm{~B}$ & $263.30 \mathrm{~B}$ \\
Dover & $29.26 \mathrm{~A}$ & $246.56 \mathrm{~B}$ & $229.85 \mathrm{~B}$ \\
Sweet Charlie & $28.22 \mathrm{~A}$ & $246.19 \mathrm{~B}$ & $227.91 \mathrm{~B}$ \\
Dover $\times$ Rosalinda & $25.65 \mathrm{~B}$ & $211.87 \mathrm{C}$ & $196.69 \mathrm{C}$ \\
IAC Guaraní & $28.28 \mathrm{~A}$ & $204.20 \mathrm{C}$ & $191.48 \mathrm{C}$ \\
Dover $\times$ Espléndida & $25.43 \mathrm{~B}$ & $194.56 \mathrm{C}$ & $175.32 \mathrm{C}$ \\
Early Bright & $13.78 \mathrm{~B}$ & $180.17 \mathrm{C}$ & $174.13 \mathrm{C}$ \\
Dover $\times$ Aichi & $28.94 \mathrm{~A}$ & $178.11 \mathrm{C}$ & $161.13 \mathrm{C}$ \\
Sweet Charlie & $17.31 \mathrm{~B}$ & $142.56 \mathrm{C}$ & $133.70 \mathrm{C}$ \\
Corea & $25.02 \mathrm{~B}$ & $119.54 \mathrm{C}$ & $105.20 \mathrm{C}$ \\
\hline & & Vernalization & $199.64 \mathrm{~B}$ \\
Non-vernalized & $22.72 \mathrm{~B}$ & $212.03 \mathrm{~B}$ & $235.63 \mathrm{~A}$ \\
Vernalized & $26.79 \mathrm{~A}$ & $249.71 \mathrm{~A}$ & $6.73^{* *}$ \\
Genotype $(\mathrm{G})$ & $3.98^{* *}$ & $6.12^{* *}$ & $6.25^{* *}$ \\
Vernalization $(\mathrm{V})$ & $7.67^{* *}$ & $6.21^{* *}$ & $0.27^{\text {ns }}$ \\
G $\times$ V & $0.47^{\text {ns }}$ & $0.26^{\mathrm{ns}}$ & 30.31 \\
Genotype CV $(\%):$ & 27.21 & 30.02 & 30.31 \\
\hline Vernalization CV $(\%):$ & 27.21 & 30.02 & \\
\hline
\end{tabular}

*Significant at the $1 \%$ probability level; ** Significant at the $5 \%$ probability level; ns $=$ not significant. The same uppercase letters in the separate genotypes and vernalization analyses show that the genotypes and vernalization treatments were not significantly different from each other according to the Scott- Knott test at the 5\% probability level.

The vernalized genotypes in this study produced 26.79 fruits plant $^{-1}$, whereas the nonvernalized plants produced 22.72 fruits plant $^{-1}$ (Table 1). These results agreed with Oliveira and Scivittaro (2009), who reported that vernalizing transplants for 21 days (around 500 hours of cold) optimized yield and the number of strawberry fruits per plant. Diel et al. (2017) also found that vernalization increased fruit production by the Camarosa and Albion varieties.

The Dover $\times$ Oso Grande genotype produced the highest total yield at $391.11 \mathrm{~g} \mathrm{plant}^{-1}$, which was greater than the Festival, Dover $\times$ Rosalinda $_{1}$, Florida Eliane, Camino Real, Dover, and Sweet

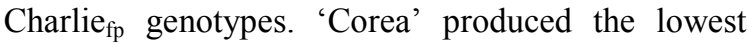
production weight $(119.54 \mathrm{~g})$, but it was not significantly different from 'Dover $\times$ Rosalinda $_{4}$ ', 'IAC Guarani', 'Dover $\times$ Esplendida', 'Early Bright', 'Dover $\times$ Aichi', and 'Sweet Charlie' (Table 1).

The vernalized genotypes had a total average yield of $249.71 \mathrm{~g} \mathrm{plant}^{-1}$, which was greater than the yields produced by the non-vernalized genotypes (average yield: $212.03 \mathrm{~g} \mathrm{plant}^{-1}$ ) (Table 1). This indicated that vernalization improved fruit production and confirmed the results obtained by
Oliveira and Scivittaro (2009), who also obtained a higher yield with vernalized transplants when the Camarosa variety was used. Diel et al. (2017), who also used Camarosa, found that the average yield from vernalized plants was $1007.50 \mathrm{~g} \mathrm{plant}^{-1}$ but only $774.16 \mathrm{~g} \mathrm{plant}^{-1}$ for non-vernalized plants. However, no differences were found between the vernalized and non-vernalized plant yields when the Albion variety was tested (207.10 and 196.91 g plant $^{-1}$, respectively).

Oliveira and Scivittaro (2009) and Diel et al. (2017) suggested that the differences between the varieties could be due to the interaction between genotype and the environment because some varieties may be better acclimatized to a particular environment, which would allow them to better express their production capacity.

The yield values recorded in this study were below the potential ideal values for the genotypes of around $500 \mathrm{~g}$. This was probably due to the plants being transplanted at a late stage during the growth cycle, which could have influenced the yield, Carvalho et al. (2013) reported that productivity decreased when the transplant date was delayed. In addition, Janisch et al. (2008) indicated that the transplanting date had a strong influence on 
strawberry production and that the transplanting date needed to be adjusted for environmental conditions because these adjustments could either increase production or reduce any decrease. Furthermore, the results from this study suggest that vernalization can also increase crop performance when the plants are transplanted late in the season.

The national average strawberry yield for Paraguay is only $300 \mathrm{~g} \mathrm{plant}^{-1}$ (MAG/DCEA, 2018), which is due to the low technology methods used by the producer and the poor availability of genotypes that are adapted to the environmental conditions in Paraguay. Gambardella and Pertuzé (2006) found that one of the common characteristics of strawberry producers in South American countries was the variation in the scale of production. There are medium to large growers ( 1 to 50 ha or more) that use modern technology and have a high commercial production capacity that can supply both fresh fruit and export markets. In contrast, there are also small producers (less than 1 ha) whose crops have few technological inputs. Their fruit is produced for domestic consumption and local markets. Ledesma et al. (2017) concluded that vernalization could help improve the survival and quality of short-day cultivars. However, vernalization alone did not ensure the production of marketable fruits at high temperatures because the size of the fruit must be a priority when selecting strawberry varieties for fruit production in the tropics.

The commercial Dover $\times$ Oso Grande genotype produced the highest average yield (374.10 grams plant $\left.{ }^{-1}\right)$, which was significantly greater than Festival, Dover $\times$ Rosalinda $_{1}$, Florida Eliane, Camino Real, Dover, and Sweet Charlie $e_{\mathrm{fp}}$. They, in turn, produced significantly greater yields than Dover $\times$ Rosalinda $_{4}$, IAC Guaraní, Dover $\times$ Esplendida, Early Bright, Dover $\times$ Aichi, Sweet Charlie, and Corea with means of between 196.69 and $105.20 \mathrm{~g} \mathrm{plant}^{-1}$ (Table 1).

Barth et al. (2019) has suggested that crosses among the current commercial cultivars could potentially be used to exploit variability as they already contain favorable alleles. In this study, the crosses in which the female genitor was Dover and the male genitor was Rosalinda or Esplendida produced the best results.

The means obtained in this research are lower than those reported by other authors such as Antunes et al. (2010), who found greater production in plants with greater accumulation of cold hours (natural) in Camarosa, Galexia, Earlibrite, Festival, Plarionfre and Sabrosa varieties with fresh mass values per plant between $716.43 \mathrm{~g}$ and $877.51 \mathrm{~g}$, far superior to this study.

The commercial yields produced by coldtreated plants (235.63 $\left.\mathrm{g} \mathrm{plant}^{-1}\right)$ were significantly greater than the yields produced by untreated plants (199.64 g plant $^{-1}$ ) (Table 1). Ledesma et al. (2017) reported that strawberries require a vernalization treatment to break a dormancy period and enhance reproductive growth. They also found that applying artificial chilling improved the growth and quality of the fruits. Oliveira and Scivittaro (2009) found that natural or artificial vernalization increased production levels and the number of fruits produced per plant. Ikram, Qureshi and Khalid (2016) reported that chilling treatment strongly improved quality and yield by increasing fruit size and weight, and the average number of fruits plant ${ }^{-1}$.

\section{Number of large, medium, small, and non- commercial fruits per plant}

There were significant differences in the numbers of large, medium, small, and noncommercial fruits per plant among the different genotypes and vernalization treatments (Table 2).

The Dover $\times$ Oso Grande, Florida Eliane, Camino Real, and Festival genotypes produced the largest number of large fruits per plant. Their numbers were not significantly different to Dover $\times$ Rosalinda $_{1}$, but all the above produced significantly more large fruits than Early Bright, Sweet Charlie $e_{\mathrm{fp}}$, and Dover. The Corea, Dover $\times$ Aichi, IAC Guarani, Sweet Charlie, Dover $\times$ Esplendida, and Dover $\times$ Rosalinda $_{4}$ genotypes had the lowest mean number of large fruits (Table 2)

Dover $\times$ Oso Grande produced the largest number of medium fruits per plant and the mean number was significantly higher than for Florida Eliane, Sweet Charlie, Camino Real, Early Bright, and Corea. Furthermore, the vernalized transplants (9.06 medium fruits plant ${ }^{-1}$ ) produced significantly more medium sized fruits than the untreated plants (8.08 fruits plant ${ }^{-1}$ ) (Table 2).

The Corea genotype, followed by Dover $x$ Aichi, produced the largest number of small fruits per plant, but the two genotypes were not significantly different. The genotype with the lowest production of small fruits was Early Bright, but it was not significantly different from Camino Real, Florida Eliane, and Festival (Table 2).

The vernalized plants produced significantly more small fruits per plant (8.86) than the nonvernalized plants (7.06). Furthermore, the results suggested that the genotypes that produced the largest number of fruit per plant tended to produce a greater quantity of small fruits (Table 2). This confirmed the results reported by Barros and Garcia (2015), who suggested that the average size of the fruits was mainly related to a genetic factor.

The highest average number of noncommercial fruits was produced by Dover $\times$ Aichi (5.04 fruits plant $^{-1}$ ), which was similar to Corea, but significantly greater than the Dover $\times$ Esplendida, Dover, Dover $\times$ Rosalinda $_{4}$, Sweet Charlie $\mathrm{fp}_{\mathrm{fp}}$, Dover $\times$ Rosalinda $_{1}$, and IAC Guarani genotypes. Early 
Bright, Camino Real, Florida Eliane, and Festival produced the lowest number of non-commercial fruits. These varieties were significantly different from Sweet Charlie and Dover $\times$ Oso Grande (Table 2).

Table 2. Variance analysis results for the numbers of large, medium, small, and non-commercial fruits per plant produced by each strawberry genotype.

\begin{tabular}{|c|c|c|c|c|}
\hline \multirow{2}{*}{ Genotypes } & \multicolumn{4}{|c|}{ Number of fruit per plant } \\
\hline & Large & Medium & Small & Non-commercial \\
\hline Dover $\times$ Oso Grande & $11.98 \mathrm{~A}$ & $12.26 \mathrm{~A}$ & $6.44 \mathrm{C}$ & $2.15 \mathrm{C}$ \\
\hline Florida Eliane & $9.85 \mathrm{~A}$ & $6.48 \mathrm{~B}$ & $2.39 \mathrm{D}$ & $0.91 \mathrm{D}$ \\
\hline Camino Real & $9.72 \mathrm{~A}$ & $5.45 \mathrm{~B}$ & $2.30 \mathrm{D}$ & $0.82 \mathrm{D}$ \\
\hline Festival & $9.65 \mathrm{~A}$ & $10.22 \mathrm{~A}$ & $3.61 \mathrm{D}$ & $1.34 \mathrm{D}$ \\
\hline Dover $\times$ Rosalinda $_{1}$ & $6.95 \mathrm{~B}$ & $10.37 \mathrm{~A}$ & $8.89 \mathrm{~B}$ & $2.89 \mathrm{~B}$ \\
\hline Early Bright & $6.07 \mathrm{C}$ & $5.00 \mathrm{~B}$ & $2.02 \mathrm{D}$ & $0.69 \mathrm{D}$ \\
\hline Sweet Charlie $_{\mathrm{fp}}$ & $5.61 \mathrm{C}$ & $9.63 \mathrm{~A}$ & $9.98 \mathrm{~B}$ & $3.00 \mathrm{~B}$ \\
\hline Dover & $4.68 \mathrm{C}$ & $11.58 \mathrm{~A}$ & $9.89 \mathrm{~B}$ & $3.11 \mathrm{~B}$ \\
\hline 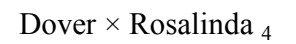 & $3.65 \mathrm{D}$ & $9.91 \mathrm{~A}$ & $9.07 \mathrm{~B}$ & $3.02 \mathrm{~B}$ \\
\hline Dover $\times$ Espléndida & $3.26 \mathrm{D}$ & $8.80 \mathrm{~A}$ & $9.54 \mathrm{~B}$ & $3.83 \mathrm{~B}$ \\
\hline Sweet Charlie & $2.98 \mathrm{D}$ & $6.41 \mathrm{~B}$ & $5.91 \mathrm{C}$ & $2.02 \mathrm{C}$ \\
\hline IAC Guaraní & $2.20 \mathrm{D}$ & $11.56 \mathrm{~A}$ & $11.69 \mathrm{~B}$ & $2.83 \mathrm{~B}$ \\
\hline Dover $\times$ Aichi & $1.78 \mathrm{D}$ & $8.17 \mathrm{~A}$ & $13.96 \mathrm{~A}$ & $5.04 \mathrm{~A}$ \\
\hline Corea & $0.45 \mathrm{D}$ & $4.19 \mathrm{~B}$ & $15.73 \mathrm{~A}$ & $4.78 \mathrm{~A}$ \\
\hline \multicolumn{5}{|c|}{ Vernalization } \\
\hline Non-vernalized & $5.52 \mathrm{~A}$ & $8.08 \mathrm{~A}$ & $7.06 \mathrm{~B}$ & $2.32 \mathrm{~B}$ \\
\hline Vernalized & $5.97 \mathrm{~A}$ & $9.06 \mathrm{~A}$ & $8.86 \mathrm{~A}$ & $2.88 \mathrm{~A}$ \\
\hline Genotype (G) & $14.80^{* *}$ & $7.09^{* *}$ & $23.08^{* *}$ & $12.77^{* *}$ \\
\hline Vernalization (V) & $0.82^{* *}$ & $3.35^{* *}$ & $13.79^{* *}$ & $7.35^{* *}$ \\
\hline $\mathrm{G} \times \mathrm{V}$ & $0.27^{\mathrm{ns}}$ & $1.05^{\mathrm{ns}}$ & $1.11^{\mathrm{ns}}$ & $0.58^{\mathrm{ns}}$ \\
\hline Genotype CV (\%): & 38.40 & 28.47 & 27.90 & 36.40 \\
\hline Vernalization CV (\%): & 38.40 & 28.47 & 27.90 & 36.40 \\
\hline
\end{tabular}

*Significant at the $1 \%$ probability level; ** Significant at the $5 \%$ probability level; ns $=$ not significant. The same uppercase letters in the separate genotypes and vernalization analyses show that the genotypes and vernalization treatments were not significantly different from each other according to the Scott- Knott test at the 5\% probability level.

Rosa et al. (2013) suggested that variations in fruit production were more affected by the environment than by the genetic constitution of a plant. The results from this study also suggested that the considerable variability in the number of small, medium, large, and non-commercial fruits was due to the late transplantation date and that this environmental factor had an important effect on fruit production.

\section{CONCLUSIONS}

The vernalization of strawberry pretransplants increased the yield and quality of the fruits, which means that it is a technique that could potentially be used in countries with subtropical or tropical climates.

There were differences in fruit yield and quality among genotypes. The results suggested that Dover $\times$ Oso Grande had the best overall plant and fruit characteristics. Furthermore, the differences among the genotypes suggest that the plant management regime must be adjusted to reflect the needs of each genotype.

\section{ACKNOWLEDGMENTS}

We thank the Instituto Paraguayo of Tecnologia Agraria for providing the strawberry genotypes and the experimental field that was used in the study.

\section{REFERENCES}

ANTUNES, L. E. C.; PERES, N. A. Strawberry production in Brazil and South America. International Journal of Fruit Science, 13: 156$161,2013$.

ANTUNES, L. E. C. et al. Yield and quality of strawberry cultivars. Horticultura Brasileira, 28: 222-226, 2010.

BARTH, E., et al. Yield and quality of strawberry hybrids under subtropical conditions. Genetics and Molecular Research, 18: 1-9, 2019.

BARROS, M. C.; GARCIA S. M. Comportamiento productivo de variedades de frutilla (Fragaria $\mathrm{x}$ ananassa Duch.) según fecha de enraizado en el noroeste de Uruguay. Agrociencia, 19:17-25, 2015.

COSTA, A. F. et al. Adaptability and stability of strawberry cultivars using a mixed model. Acta 
Scientiarum Agronomy, 37: 435-440, 2014.

CARVALHO, S. F. et al. Comportamento e qualidade de cultivares de morango (Fragaria $\mathrm{x}$ ananassa Duch.) na região de pelotas-RS. Revista Iberoamericana de Tecnología Postcosecha, 14: 176-180, 2013.

DI RIENZO, J. A. et. al. InfoStat versión 2015. Grupo InfoStat. Universidad Nacional de Córdoba. Argentina. 2015.

DIEL, M. I. et al. Artificial vernalization in strawberry plants: phyllochron, production and quality. Australian Journal of Crop Science, 11: 1315-1319, 2017.

FONTANA, D. C. et. al. The performance of strawberry cultivars in Southern Brazil. International Journal of Current Research. 8: 33889-33893, 2016.

GAMBARDELLA, M.; PERTUZÉ, R. Strawberry production in South America. Acta Horticulturae, 708: 419-424, 2006.

GUILLEN, O. M.; ZARZA, H. S.; DELGADO, V. R. Validación de cultivares de frutilla. In: GUILlEN, O. M. et. al. (Eds.). Compendio de resultados de investigación: Proyecto IPTA CONACYT 14-INV-447: Validación y difusión de prácticas agronómicas sustentables para el mejoramiento de la tecnología de producción de la frutilla en la zona frutillera de la cuenca del Lago Ypacarai, Caacupé: CIHB/IPTA, 2019. cap. 1, p. 7-11.

HEIDE, O. M.; STAVANG, J. A.; SØNSTEBY, A. Physiology and genetics of flowering in cultivated and wild strawberries-a review. The Journal of Horticultural Science and Biotechnology, 88: 1$18,2013$.

IKRAM, S.; QURESHI, K. M.; KHALID, N. Flowering and fruiting responses of strawberry to growth hormone and chilling grown under tunnel conditions. Pakistan Journal of Agricultural Sciences, 53: 911-916, 2016.

ISATOMI, T; RAIDAN, L. Cultivo de la frutilla. In: ISHJIJIMA, T.; OKAWARA, Y. (eds). Manual de técnicas de cultivo de hortalizas de fruta (Tomate, Melón, Frutilla). Caacupé, PY: JICA/MAG, 2002. v. 1 , cap. 4 , p. 187-222.

JANISCH, I. et al. Produção de frutos do morangueiro em diferentes épocas de plantio em Santa Maria, RS. Horticultura Brasileira, 26: 19751978, 2008.
LAVÍN, A.; MAUREIRA, M. La frutilla Chilena de fruto blanco: Proyecto de desarrollo de las comunas pobres de la zona de secano (PRODECOP-SECANO), 2. ed. Cauquenes: INIA, 2019, 34 p. (Boletín INIA, 39).

LEDESMA, N. A. et al. Chilling Differentially Affects Strawberries Grown under HighTemperature Conditions. Philippine Agricultural Scientist, 100: 211-221, 2017.

LIETEN, F.; KINET, J. M.; BERNIER, G. Effect of prolonged cold storage on the production capacity of strawberry plants. Scientia Horticulturae, 60: 213$219,1995$.

LOPEZ, O. et al. Estudio de reconocimiento de suelos, capacidad de uso de la tierra y propuesta de ordenamiento territorial preliminar de la región oriental del Paraguay. Asunción: MAG. 1995. $246 \mathrm{p}$

MINISTERIO DE AGRICULTURA Y GANADERÍA. DIRECCIÓN DE CENSOS Y ESTADÍSTICAS AGROPECUARIAS - MAG/ DCEA. Producción agropecuaria año agrícola 2017/2018. San Lorenzo, 2018. 45 p.

OLIVEIRA, R. P; SCIVITTARO, W. B. Produção de frutos de morango em função de diferentes períodos de vernalização das mudas. Horticultura Brasileira, 27: 91-95, 2009.

OVIEDO, V. R. S. et al. Postharvest quality of strawberry (Fragaria $\chi$ ananassa (Duchesne ex Weston) Duchesne ex Rozier) genotypes according to vernalization, Acta Agronómica, 67: 208-214, 2018 .

ROSA, H. T. et al. Crescimento vegetativo e produtivo de duas cultivares de morango sob épocas de plantio em ambiente subtropical. Revista Ciência Agronômica, 44: 604-613, 2013.

RUAN. J. et al. Flowering and Fruiting of Dayneutral and Ever-bearing Strawberry Cultivars in High-elevation for Summer and Autumn Fruit Production in Korea. Horticulture Environmental Biotechnology, 54: 109-120, 2013

SILVA, M. S; DIAS M. S. C; PACHECO D. D. Desempenho produtivo e qualidade de frutos de morangueiros produzidos no norte de Minas Gerais. Horticultura Brasileira, 33: 251-256, 2015.

TAIZ, L. et al. Fisiología e desenvolvimento vegetal. 6. ed. Porto Alegre, RS: Artmed, 2017. 898 p. 